\title{
BIOSYNTHESES OF NEW BLEOMYCINS
}

\author{
Akio Fuji*, Tomohisa Takita, Nobuyoshi Shimada* \\ and Hamao Umezawa
}

Institute of Microbial Chemistry, Kamiosaki, Shinagawa-ku, Tokyo, Japan

(Received for publication November 6, 1973)

\begin{abstract}
Bleomycins, a group of glycopeptide antibiotics differ from one another in their terminal amine moieties. ${ }^{14} \mathrm{C}$-Methyl-labeled 3-aminopropyl-dimethylsulfonium was confirmed to be incorporated into the amine moiety of bleomycin $\mathrm{A}_{2}$. Addition of amines of bleomycin $\mathrm{A}_{2}, \mathrm{~A}_{2}{ }^{\prime}-\mathrm{a}, \mathrm{A}_{2}{ }^{\prime}-\mathrm{b}, \mathrm{A}_{2}{ }^{\prime}-\mathrm{c}, \mathrm{A}_{5}, \mathrm{~B}_{2}$ and $\mathrm{B}_{4}$ to fermentation media increased the rate of production of the bleomycin which contained the added amine. Addition of the amines of bleomycins $\mathrm{A}_{2}, \mathrm{~A}_{2}{ }^{\prime}-\mathrm{b}, \mathrm{A}_{2}{ }^{\prime}-\mathrm{c}, \mathrm{A}_{5}, \mathrm{~B}_{2}$ and $\mathrm{B}_{4}$ suppressed production of the other natural bleomycins almost completely. New bleomycins which contained deiminated products of amines of $\mathrm{B}_{2}$ and $\mathrm{B}_{4}$ were isolated from media to which these amines were added. Amines which were not found in natural bleomycins also suppressed production of natural bleomycins and caused production of new biosynthetic bleomycins which contained the added amines. The data of the production of these new bleomycins suggested a relationship of the incorporation rates to the structures of possible metabolites.
\end{abstract}

As reported in previous papers ${ }^{1,21}$, various bleomycins are produced by Streptomyces verticillus, and they have been shown ${ }^{31}$ to differ from one another in their terminal amine moieties $^{4,5)}$. These differences suggested that addition of such amines to the fermentation medium might increase the production of specific bleomycins. As briefly reviewed in a general paper ${ }^{6)}$, the amines of bleomycins $\mathbf{A}_{2}, \mathbf{A}_{2}{ }^{\prime}-a, \mathbf{A}_{2}{ }^{\prime}-b, A_{5}$ and $\mathbf{B}_{4}$ added to a fermentation medium were apparently incorporated into bleomycins. We now report that not only the amines of nat.ral bleomycins but also unnatural amines are utilized in biosyntheses of bleomycins and the addition of them caused the selective production of new bleomycins.

\section{Materials and Methods}

Fermentation: The seed $(15 \mathrm{ml})$ was prepared by the shake-culturing Streptomyces verticillus (ATCC 15003) at $27^{\circ} \mathrm{C}$ for 48 hours in $100 \mathrm{ml}$ of the following medium in an Erlenmeyer flask of 500-ml volume: $1.0 \%$ glucose, $1.0 \%$ starch, $0.75 \%$ peptone (Kyokuto Seiyaku Co., Ltd., Tokyo), $0.75 \%$ meat extract (Mikuni Kagaku Co., Ltd., Tokyo), $0.3 \% \mathrm{NaCl}, 0.02 \%$ Pronal ST-1 (antifoam agent, Toho Chemical Industry Co., Ltd., Tokyo), pH 7.2 before sterilization. It was inoculated into $100 \mathrm{ml}$ of the following production medium and grown at $27^{\circ} \mathrm{C}$ for $8 \sim 10$ days on a rotary shaking machine (190 r.p.m.): $6.4 \%$ millet jelly (Asadaame Shokuhin Co., Ltd., Kanagawa-ken, Japan), $0.5 \%$ glucose, $3.5 \%$ soybean meal, $0.75 \%$ corn steep liquor (Ajinomoto Co., Ltd., Tokyo), $0.3 \% \mathrm{NaCl}, 0.1 \% \mathrm{~K}_{2} \mathrm{HPO}_{4}, 0.05 \% \mathrm{ZnSO}_{4} \cdot 7 \mathrm{H}_{2} \mathrm{O}, 0.01 \% \mathrm{CuSO}_{4} \cdot 5 \mathrm{H}_{2} \mathrm{O}, 0.2 \%$ $\mathrm{NaNO}_{3}, 0.01 \%$ Pronal ST-1, pH 6.5 before sterilization. Unless specially noted, a neutralized aqueous solution of an amine was sterilized by Millipore filter filtration and added to the medium at the start of the culture.

Assay of antibacterial activity: Antibacterial activity was assayed by a cylinder-agar plate method using Mycobacterium 607 as the test organism and copper-free bleomycin $\mathrm{A}_{2}$ sulfate

* A. Fuiri and N. Shimada: Research Laboratories of Nippon Kayaku Co., Ltd. 
was used as the standard. Copper-free bleomycin $\mathrm{A}_{2}$ free base was defined to be $1,000 \mathrm{units} / \mathrm{mg}$. Samples were diluted with $\mathrm{m} / 10$ phosphate buffer at $\mathrm{pH} 6.8$.

The amines added to the fermentation medium: The amines shown in Table 1 were prepared by the authors as described in a previous papers ${ }^{4,5)}$, and the amines shown in Table 2 except commercially available ones were synthesized by Mr. K. TAKADA, Research Laboratory of Nippon Kayaku Co., Ltd. Radioactive 3-aminopropyl-dimethylsulfonium chloride was synthesized by S-methylation of N-benzoyl-3-methylthiopropylamine with ${ }^{14} \mathrm{CH}_{3} \mathrm{I}$ followed by acid hydrolysis.

Extraction of bleomycins from cultured broth: Filtered broth was passed through a column of Amberlite IRC-50 (H-form). The adsorbed bleomycin was eluted with $0.5 \mathrm{~N} \mathrm{HCl}$. The eluate was adjusted to $\mathrm{pH} 6.5$ with $1 \mathrm{~N} \mathrm{NaOH}$ and charged on a carbon column. After washing, bleomycin was eluted with a mixture of acetone and $0.02 \mathrm{~N} \mathrm{HCl}(1: 1)$. After neutralization with Dowex 44 (OH-form), the fractions containing bleomycins were combined and evaporated under reduced pressure. A mixture of bleomycins in the crude powder thus obtained was further purified by alumina chromatography using $80 \%$ aqueous methanol as the developing solvent and Sephadex G 25 chromatography.

Analysis of bleomycin composition: Bleomycin composition in the mixture obtained by the process described in previous paragraph was analyzed by CM-Sephadex C $25(100 \mathrm{ml})$ column chromatography with a gradient of ammonium formate from 0.05 to $1.0 \mathrm{M}$ (the total solvent volume was $1,000 \mathrm{ml}$ ). The eluate was taken in $5-\mathrm{ml}$ fractions, and the optical density measured at $292 \mathrm{~nm}$.

Identification of components: Purity of each bleomycin isolatated by CM-Sephadex column chromatography was examined by thin-layer chromatography (Silica gel G: $\mathrm{MeOH}-10 \%$ $\mathrm{AcONH}_{4}-10 \% \mathrm{NH}_{4} \mathrm{OH}, 10: 9: 1$ ) and paper chromatography (Toyo No. 51 filter paper, $10 \%$ $\left.\mathrm{NH}_{4} \mathrm{Cl}\right)^{2}$, and the terminal amine of each bleomycin was identified by two-dimensional paper electrophoresis and chromatography of the total acid hydrolyzate as described in a previous paper $^{5 !}$.

\section{Results and Discussion}

The analysis of a bleomycin mixture produced in a natural medium described in a previous section is shown in Fig. $1 \mathrm{~b}$. It contains bleomycins $\mathrm{A}_{1}$, demethyl- $\mathrm{A}_{2}, \mathrm{~B}_{1}{ }^{\prime}, \mathrm{A}_{2}, \mathrm{~A}_{2}{ }^{\prime}$-a, $\mathrm{A}_{2}{ }^{\prime}$-b, $\mathrm{A}_{2}{ }^{\prime}-\mathrm{c}, \mathrm{B}_{2}, \mathrm{~A}_{5}, \mathrm{~B}_{4}, \mathrm{~A}_{6}$ and $\mathrm{B}_{6}$. Though the total bleomycin produced in this medium was not high, we studied the biosynthesis of various bleomycins under these conditions in which bleomycin appeared at 4 th or 5 th day and the maximum production was obtained at 8 th to 10 th day. Preliminary experiments in which unlabeled 3-aminopropyl-dimethylsulfonium was added to the medium suggested the incorporation of this amine into bleomycin $\mathrm{A}_{2}$. This was confirmed by addition of ${ }^{14} \mathrm{C}$-methyl-labeled 3-aminopropyl-dimethylsulfonium chloride to the medium. Ninety $\mathrm{mg}\left(100 \mu \mathrm{Ci}, 2.2 \times 10^{8} \mathrm{dpm}\right)$ of this amine was added to $100 \mathrm{ml}$ of the medium at 48 hours of the shaking culture. After 6 days the cultured broth was harvested. The filtrate $(140 \mathrm{ml})$ which was combined with the wash contained 152 units $/ \mathrm{ml}$ of bleomycin and $1.5 \times 10^{8}$ $\mathrm{dpm}$ radioactivity. To this filtrate was added $780 \mathrm{ml}$ of the unlabeled filtrate (114 units/ml) which was obtained by a similar shaking culture with addition of the unlabeled amine. Bleomycin in the combined filtrate was extracted by the successive application of Amberlite IRC-50 chromatography, carbon chromatography and alumina chromatography, and $62 \mathrm{mg}$ (871 units $\left./ \mathrm{mg}, 7.2 \times 10^{6} \mathrm{dpm}\right)$ of crude bleomycin was isolated. The analysis of $7.8 \mathrm{mg}(9.4 \times$ $10^{5} \mathrm{dpm}$ ) of the sample is shown in Fig. 1 a. Fractions $76 \sim 85$ showed a major peak of radioactivity $\left(5.7 \times 10^{5} \mathrm{dpm}\right)$, and coincidence of this radioactivity with bleomycin $\mathrm{A}_{2}$ was confirmed. These fractions were combined and desalted after dilution with $4.8 \mathrm{mg}$ of unlabeled $\mathrm{A}_{2}$ as carrier 
to give $5.4 \mathrm{mg}$ of labeled bleomycin $\mathrm{A}_{2}\left(5.6 \times 10^{4} \mathrm{dpm} / \mathrm{mg}\right)$. Acid hydrolysis of the labeled $\mathrm{A}_{2}$ gave labeled terminal amine, but the other hydrolysis products did not show any significant radioactivity. The fractions in another peak of the radioactivity in Fig. 1 a did not contain any bleomycin, because they had no absorbance at $292 \mathrm{~nm}$.

Thus, it became evident that the added amine was incorporated into the terminal amine moiety of bleomycin $A_{2}$. Moreover, as seen in Fig. $1 \mathrm{a}$ and $1 \mathrm{~b}$, the addition of the amine of $\mathrm{A}_{2}$ suppressed almost completely the production of the other natural bleomycins. This precursor effect was also found with the terminal amines of the other natural bleomycins except for those of $A_{1}$, demethyl- $A_{2}$ and $A_{6}$. The results are summarized in Table 1. In these experiments, the

Fig. 1. CM-Sephadex C-25 chromatography of

a) Bleomycins produced by addition of $\quad$ b) Control: Bleomycins produced without ${ }^{14} \mathrm{CH}_{3}-\mathrm{S}-\mathrm{CH}_{2}-\mathrm{CH}_{2}-\mathrm{CH}_{2}-\mathrm{NH}_{2} \cdot \mathrm{Cl}^{-}$ addition of the amine

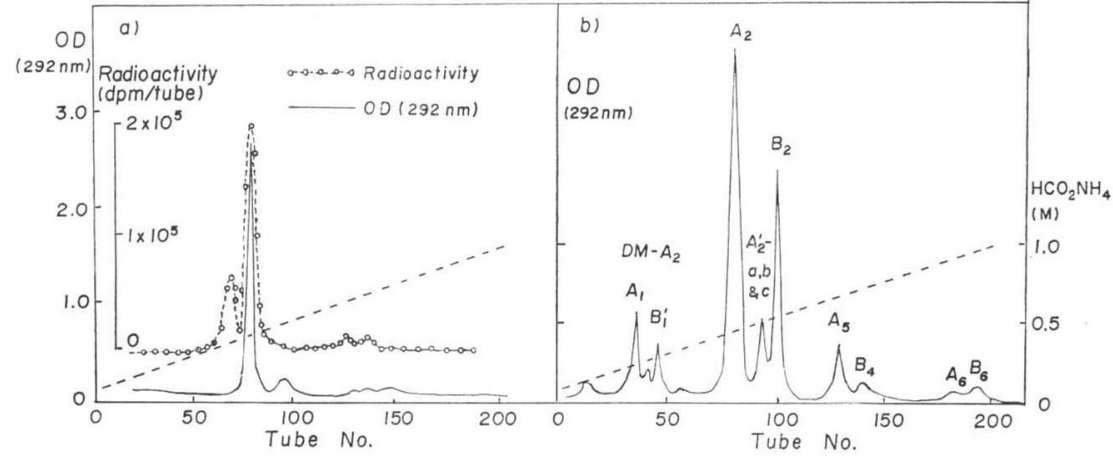

Table 1. Bleomycins produced by addition of terminal amines of natural bleomycins

\begin{tabular}{|c|c|c|c|c|}
\hline \multicolumn{3}{|c|}{ Added amine } & \multirow[b]{2}{*}{ Produced bleomycins $(\%)$} & \multirow[b]{2}{*}{$\begin{array}{c}\text { Control } \\
(\%)\end{array}$} \\
\hline Origin & Structure & $\begin{array}{c}\text { Concen- } \\
\text { tration } \\
(\mathrm{mg} / \mathrm{ml})\end{array}$ & & \\
\hline $\mathrm{A}_{1}$ & $\mathrm{NH}_{2}-\mathrm{CH}_{2}-\mathrm{CH}_{2}-\mathrm{CH}_{2}-\mathrm{SO}-\mathrm{CH}_{3} \cdot \frac{1}{2} \mathrm{H}_{2} \mathrm{SO}_{4}$ & 8.0 & almost same as control & 9.2 \\
\hline $\mathrm{DM}-\mathrm{A}_{2}$ & $\mathrm{NH}_{2}-\mathrm{CH}_{2}-\mathrm{CH}_{2}-\mathrm{CH}_{2}-\mathrm{S}-\mathrm{CH}_{3} \cdot \mathrm{HCl}$ & 5.0 & almost same as control & 2.4 \\
\hline $\mathrm{A}_{2}$ & $\mathrm{NH}_{2}-\mathrm{CH}_{2}-\mathrm{CH}_{2}-\mathrm{CH}_{2}-\stackrel{+}{\mathrm{S}}-\left(\mathrm{CH}_{3}\right)_{2} \cdot \mathrm{Cl}^{-} \cdot \mathrm{HCl}$ & 1.0 & $\mathrm{~A}_{2} 82$ & 54.5 \\
\hline $\mathrm{A}_{2}^{\prime}-\mathrm{a}$ & $\mathrm{NH}_{2}-\mathrm{CH}_{2}-\mathrm{CH}_{2}-\mathrm{CH}_{2}-\mathrm{CH}_{2}-\mathrm{NH}_{2} \cdot 2 \mathrm{HCl}$ & 4.0 & $\mathrm{~A}_{2}^{\prime}-\mathrm{a} 24$ & \\
\hline $\mathrm{A}_{2}{ }^{\prime}-\mathrm{b}$ & $\mathrm{NH}_{2}-\mathrm{CH}_{2}-\mathrm{CH}_{2}-\mathrm{CH}_{2}-\mathrm{NH}_{2} \cdot 2 \mathrm{HCl}$ & 2.0 & $\mathrm{~A}_{2}{ }^{\prime}-\mathrm{b} 85$ & 3.6 \\
\hline $\mathrm{A}_{2}^{\prime}-\mathrm{c}$ & $\mathrm{NH}_{2}-\mathrm{CH}_{2}-\mathrm{CH}_{2} \|_{\underbrace{\mathrm{H}}}^{-\mathrm{N}} \cdot \mathrm{N}^{\prime \prime} \mathrm{HCl}$ & 1.0 & $\mathrm{~A}_{2}{ }^{\prime}-\mathrm{c} 93$ & \\
\hline $\mathrm{B}_{2}$ & $\begin{array}{c}\mathrm{NH}_{2}-\mathrm{CH}_{2}-\mathrm{CH}_{2}-\mathrm{CH}_{2}-\mathrm{CH}_{2}-\mathrm{NH}-\mathrm{C}-\mathrm{NH}_{2} \cdot \mathrm{H}_{2} \mathrm{SO}_{4} \\
\mathrm{NH}\end{array}$ & 2.0 & $\mathrm{~B}_{2} 45$, a new BLM $34 * *$ & 26.7 \\
\hline $\mathbf{B}_{4}$ & 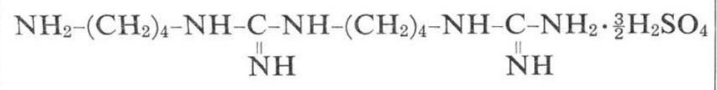 & 0.53 & $\mathrm{~B}_{4} 38$, a new BLM $40^{* *}$ & 2.4 \\
\hline $\mathrm{A}_{5}$ & $\mathrm{NH}_{2}-\left(\mathrm{CH}_{2}\right)_{3}-\mathrm{NH}-\left(\mathrm{CH}_{2}\right)_{4}-\mathrm{NH}_{2} \cdot 3 \mathrm{HCl}$ & 0.36 & $A_{5} 100$ & 1.3 \\
\hline $\mathrm{A}_{6}$ & $\mathrm{NH}_{2}-\left(\mathrm{CH}_{2}\right)_{3}-\mathrm{NH}-\left(\mathrm{CH}_{2}\right)_{4}-\mathrm{NH}-\left(\mathrm{CH}_{2}\right)_{3}-\mathrm{NH}_{2} \cdot 4 \mathrm{HCl}$ & 0.30 & $\mathrm{~A}_{5} c a \cdot 100, \mathrm{~A}_{6}$ trace & trace \\
\hline
\end{tabular}

* Composition of bleomycins produced without addition of amine.

** Deiminated products of terminal guanidino groups of bleomycins $\mathrm{B}_{2}$ and $\mathrm{B}_{4}$, respectively. 
Table 2. New bleomycins produced by addition of amines

\begin{tabular}{|c|c|c|c|c|}
\hline \multicolumn{3}{|c|}{ Added amine } & \multirow{2}{*}{$\begin{array}{c}\text { Content of } \\
\text { corresponding } \\
\text { bleomycin } \\
\text { in the product } \\
(\%)\end{array}$} & \multirow{2}{*}{$\begin{array}{c}\text { Antibacterial } \\
\text { activity of } \\
\text { corresponding } \\
\text { bleomycin } \\
(\mathrm{u} / \mathrm{mg})\end{array}$} \\
\hline & Structure & $\begin{array}{l}\text { Concen- } \\
\text { tration } \\
(\mathrm{mg} / \mathrm{ml})\end{array}$ & & \\
\hline (I) & $\mathrm{NH}_{2}-\left(\mathrm{CH}_{2}\right)_{2}-\mathrm{NH}_{2} \cdot 2 \mathrm{HCl}$ & 2.0 & 86 & 2,072 \\
\hline (II) & $\mathrm{NH}_{2}-\left(\mathrm{CH}_{2}\right)_{3}-\mathrm{N}\left(\mathrm{CH}_{3}\right)_{2} \cdot 2 \mathrm{HCl}$ & 2.0 & 100 & 810 \\
\hline (III) & $\mathrm{NH}_{2}-\left(\mathrm{CH}_{2}\right)_{3}-\mathrm{N} \quad \mathrm{O} \cdot 2 \mathrm{HCl}$ & 0.1 & 100 & 592 \\
\hline$(\mathbf{I V})$ & $\begin{array}{c}\mathrm{NH}_{2}-\left(\mathrm{CH}_{2}\right)_{3}-\mathrm{NH}-\mathrm{C}-\mathrm{NH}_{2} \cdot 2 \mathrm{HCl} \\
\mathrm{NH}\end{array}$ & 2.0 & 100 & 2,830 \\
\hline$(\mathbf{V})$ & $\mathrm{NH}_{2}-\left(\mathrm{CH}_{2}\right)_{3}-\mathrm{NH}-\left(\mathrm{CH}_{2}\right)_{3}-\mathrm{NH}_{2} \cdot 3 \mathrm{HCl}$ & 0.5 & $66(13)^{*}$ & 2,067 \\
\hline$(\mathrm{VI})$ & $\begin{array}{c}\mathrm{NH}_{2}-\left(\mathrm{CH}_{2}\right)_{3}-\mathrm{N}-\left(\mathrm{CH}_{2}\right)_{3}-\mathrm{NH}_{2} \cdot 3 \mathrm{HCl} \\
\mathrm{CH}_{3}\end{array}$ & 0.5 & $65(35)^{*}$ & 1,671 \\
\hline (VII) & $\mathrm{NH}_{2}-\left(\mathrm{CH}_{2}\right)_{3}-\mathrm{NH}-\left(\mathrm{CH}_{2}\right)_{3}-\mathrm{NH}-\mathrm{C}_{4} \mathrm{H}_{9} \cdot 3 \mathrm{HCl}$ & 0.5 & 100 & 5,840 \\
\hline (VIII) & $\begin{array}{c}\mathrm{NH}_{2}-\left(\mathrm{CH}_{2}\right)_{3}-\mathrm{NH}-\left(\mathrm{CH}_{2}\right)_{3}-\mathrm{NH}-\mathrm{CH}-\mathrm{Ph} \cdot 3 \mathrm{HCl} \\
\mathrm{CH}_{3}\end{array}$ & 0.9 & 100 & 9,010 \\
\hline
\end{tabular}

* Content of the des-3-aminopropyl derivative

amines were added at the start of the shaking culture, because the precursor effect appeared most clearly when added at the start.

The terminal amines of bleomycins $A_{1}$ and demethyl $A_{2}\left(D M-A_{2}\right)$ were not incorporated even at high concentrations in the medium, and addition of these amines to fermentation media did not suppress the production of the other natural bleomycins. Addition of $\mathrm{A}_{2}{ }^{\prime}-\mathrm{b}$ amine caused the selective production of bleomycin $\mathrm{A}_{2}{ }^{\prime}-\mathrm{b}$, while addition of $\mathrm{A}_{2}{ }^{\prime}$-a amine (putrescine) did not suppress the production of the other natural bleomycins strongly. This difference between precursor effects of these amines may be due to the easier metabolism of $\mathbf{A}_{2}{ }^{\prime}$-a amine than $\mathrm{A}_{2}{ }^{\prime}-\mathrm{b}$ amine. $\mathrm{A}_{2}{ }^{\prime}$-c amine (histamine) was well incorporated.

Addition of $\mathrm{B}_{2}$ amine (agmatine) increased the production of $\mathrm{B}_{2}$ and suppressed the production of the other natural bleomycins. However, in this case, besides bleomycin $\mathrm{B}_{2}$, a new bleomycin which was negative ninhydrin and SAKAGUCHI reactions and less basic than $B_{2}$ was produced. From the acid-hydrolyzate of this new bleomycin, N-4-aminobutyl-urea, the deiminated product of agmatine was isolated and the terminal amine moiety of this new bleomycin was determined.

With the addition of $\mathrm{B}_{4}$ amine, a similar result was obtained. Besides $\mathbf{B}_{4}$, a new bleomycin which was negative in ninhydrin and SAKAGUCHI reactions and less basic than $B_{4}$ was also produced. The basicity of this bleomycin was similar to that of $\mathrm{B}_{2}$ as judged by high-voltage paper electrophoresis ${ }^{4}$. Thus, the terminal amine of this bleomycin was suggested to be the deiminated product of the terminal guanidino group of $\mathrm{B}_{4}$ amine, which is shown in Table 1 .

Spermidine was very efficiently incorporated into bleomycin $A_{5}$ and addition of its $0.3 \mathrm{mg} / \mathrm{ml}$ completely suppressed the production of the other bleomycins. Addition of $\mathrm{A}_{6}$ amine (spermine) caused the selective production of bleomycin $A_{5}$, but not $A_{6}$. It suggests that spermine is transformed into spermidine before incorporation into bleomycin.

The above results suggested that aminoalkyl derivatives of basic substances such as amine, guanidine, sulfonium etc. could be incorporated into the terminal amine moiety of bleomycin. 
The results of testing the incorporation of such amines are shown in Table 2. 1,2-Diaminoethane (I) was incorporated almost to the same extent as 1,3-diaminopropane ( $\mathbf{A}_{2}{ }^{\prime}-\mathrm{b}$ amine). This suggests that 2-aminoethyl derivatives of basic compounds are incorporated as well as the 3-aminopropyl derivatives.

A strong precursor effect was observed with N-3-aminopropyl derivatives of dimethylamine (II), morpholine (III) and guanidine (IV). The addition of these amines caused the completely selective production of bleomycins which contained the amines added. In the case of 3guanidopropylamine (IV), unlike $\mathbf{B}_{2}$ and $\mathbf{B}_{4}$ amines, a bleomycin having the deiminated amine was not produced.

Addition of $\mathrm{N}$-(3-aminopropyl)-1,3-diaminopropane (V) and its $\mathrm{N}$-methyl derivative (VI) gave the corresponding bleomycins (66\% and $65 \%$ respectively) and their des-3-aminopropyl derivatives (13\% and $35 \%$ respectively). As already described, when $\mathrm{A}_{6}$ amine was added, the product was exclusively $\mathbf{A}_{5}$, which contained the des-3-aminopropyl derivative of $\mathbf{A}_{6}$ amine. These results might be related. It was noticed that $\mathrm{N}^{\prime}$-n-butyl (VII) and $\mathrm{N}^{\prime}$-(1-phenylethyl) (VIII) derivatives of $\mathrm{N}$-(3-aminopropyl)-1, 3-diaminopropane gave only the bleomycins containing these amines and did not give the related bleomycins in which the 3-aminopropyl group had been removed.

The results described above indicate that the bleomycin-producing strain is able to utilize various types of amines for biosyntheses of various bleomycins. It suggests that the same strain can produce different bleomycin mixtures depending on use of different natural nitrogen sources.

\section{References}

1) Umezawa, H.; K. Maeda, T. Takeuchi \& Y. OKami: New antibiotics, bleomycins A and B. J. Antibiotics, Ser. A 19: 200 209, 1966

2) Umezawa, H.; Y. Suhara, T. Takita \& K. Maeda: Purification of bleomycins. J. Antibiotics, Ser. A 19: $210 \sim 215,1966$

3) Takita, T.; Y. Muraoka, T. Yoshioka, A. Fuji, K. Maeda \& H. Umezawa: The chemistry of bleomycin. IX. The structures of bleomycin and phleomycin. J. Antibiotics 25: 755 758, 1972

4) Fujil, A.; T. Takita, K. Maeda \& H. Umezawa: New components of bleomycin. J. Antibiotics 26: $396 \sim 397,1973$

5) Fujil, A.; T. Takita, K. Maeda \& H. Umezawa: Chemistry of bleomycin. XI. The structures of the terminal amines. J. Antibiotics 26: 398 399, 1973

6) Umezawa, H.: Natural and artificial bleomycins: Chemistry and antitumor activity. Pure \& Appl. Chem. 28: 665 680, 1971 